\title{
Evolution of microstructure and hardness during artificial aging of an ultrafine-grained Al-Zn-Mg- Zr alloy processed by high pressure torsion
}

\author{
Jenő Gubicza ${ }^{1, *}$, Moustafa El-Tahawy², János L. Lábár ${ }^{1,3}$, Elena V. Bobruk ${ }^{4}$, \\ Maxim Yu Murashkin ${ }^{4}$, Ruslan Z. Valiev ${ }^{4}$, and Nguyen Q. Chinh ${ }^{1}$ \\ ${ }^{1}$ Department of Materials Physics, Eötvös Loránd University, P.O.B. 32, Budapest H-1518, Hungary \\ ${ }^{2}$ Department of Physics, Faculty of Science, Tanta University, Tanta 31527, Egypt \\ ${ }^{3}$ Institute for Technical Physics and Materials Science, Centre for Energy Research, Budapest, Hungary \\ ${ }^{4}$ Institute of Physics of Advanced Materials, Ufa State Aviation Technical University, 12 K. Marx Str, Ufa, Russia 450008
}

Received: 13 May 2020

Accepted: 24 August 2020

Published online:

11 September 2020

(C) The Author(s) 2020

\begin{abstract}
An ultrafine-grained (UFG) Al-4.8\% Zn- $1.2 \% \mathrm{Mg}-0.14 \% \mathrm{Zr}$ (wt $\%$ ) alloy was processed by high pressure torsion (HPT) technique and then aged at 120 and $170{ }^{\circ} \mathrm{C}$ for $2 \mathrm{~h}$. The changes in the microstructure due to this artificial aging were studied by X-ray diffraction and transmission electron microscopy. It was found that the HPT-processed alloy has a small grain size of about $200 \mathrm{~nm}$ and a high dislocation density of about $8 \times 10^{14} \mathrm{~m}^{-2}$. The majority of precipitates after HPT are Guinier-Preston (GP) zones with a size of $\sim 2 \mathrm{~nm}$, and only a few large particles were formed at the grain boundaries. Annealing at 120 and $170{ }^{\circ} \mathrm{C}$ for $2 \mathrm{~h}$ resulted in the formation of stable $\mathrm{MgZn}_{2}$ precipitates from a part of the GP zones. It was found that for the higher temperature the fraction of the $\mathrm{MgZn}_{2}$ phase was larger and the dislocation density in the $\mathrm{Al}$ matrix was lower. The changes in the precipitates and the dislocation density due to aging were correlated to the hardness evolution. It was found that the majority of hardness reduction during aging was caused by the annihilation of dislocations and some grain growth at $170{ }^{\circ} \mathrm{C}$. The aging effect on the microstructure and the hardness of the HPT-processed specimen was compared to that observed for the UFG sample processed by equal-channel angular pressing. It was revealed that in the HPT sample less secondary phase particles formed in the grain boundaries, and the higher amount of precipitates in the grain interiors resulted in a higher hardness even after aging.
\end{abstract}

Handling Editor: P. Nash.

Address correspondence to E-mail: jeno.gubicza@ttk.elte.hu 


\section{Introduction}

Severe plastic deformation (SPD) is an effective and extensively studied way to produce ultrafine-grained (UFG) metals and alloys in the bulk form [1]. The two most frequently used SPD methods are the equalchannel angular pressing (ECAP) and the high pressure torsion (HPT) $[2,3]$. These techniques yield very hard materials due to the high dislocation density and the small grain size developed during SPD [1,4]. Additional hardening can be achieved by post-SPD annealing due to segregation of solutes to lattice defects (e.g., to dislocations, stacking faults and grain boundaries) [5-8], annihilation of mobile dislocations [9], rearrangement of the remaining dislocations into harder configurations [10-12], clustering of excess vacancies [13, 14] and formation of precipitates [15-17]. The latter effect is very important in agehardenable materials, such Al-Zn-Mg alloys (7xxx series), where the precipitate structure developed during SPD and subsequent annealing may differ from that formed in coarse-grained counterparts during conventional aging heat treatments. It should emphasized that due to their technological and practical importance, many features of $\mathrm{AlZnMg}$ alloys have been studied in details [5, 6, 18-24].

In a recent publication, we investigated the microstructure development and mechanical properties of an ECAP-processed UFG Al-4.8\% Zn$1.2 \% \mathrm{Mg}-0.14 \% \mathrm{Zr}$ (wt \%) alloy aged at 120 and $170{ }^{\circ} \mathrm{C}$ up to the aging time of $2 \mathrm{~h}$ [25]. The evolution of hardness versus the time of heat treatment can be seen in Fig. 1a. Although the hardness for the sample processed by ECAP at room temperature (RT) was very high ( $1470 \mathrm{MPa})$, after subsequent aging at both 120 and $170{ }^{\circ} \mathrm{C}$ for $2 \mathrm{~h}$ the hardness decreased below the value characteristic to the conventional $\mathrm{T} 6$ heat treatment $(\sim 1280 \mathrm{MPa})$. It was found that the hardness decrease was mainly caused by the change of precipitates during annealing. Namely, $\eta-\mathrm{MgZn}_{2}$ precipitates formed from the GP zones and an additional particle coarsening also occurred. A large amount of $\mathrm{MgZn}_{2}$ precipitates were found in the grain boundaries after ECAP and the fraction and size of these particles increased at the expense of the precipitates in the grain interiors. Thus, finally the initially ECAP-processed sample became softer than the coarse-grained counterpart subjected to the conventional T6 aging. The other very popular technique of SPD, the HPT process was also applied on this alloy, and the corresponding hardness evolution versus the artificial aging time can be seen in Fig. 1b. Although the hardness of the HPT-processed sample ( $1970 \mathrm{MPa}$ ) was much higher than that for the ECAP specimen, the same aging treatment caused similar or slightly lower softening in percentage $(20-30 \%)$ as for the ECAP-processed sample. At the same time, it is evident from Fig. 1 that the hardness of the HPT-processed specimen remained higher even after aging for $2 \mathrm{~h}$ than the value characteristic for T6 conventional aging treatment. We aimed at investigating this difference by studying the effect of aging on the microstructure of the HPT-processed alloy.

In this paper, the mentioned UFG Al-4.8\% Zn$1.2 \% \mathrm{Mg}-0.14 \% \mathrm{Zr}$ (wt\%) alloy processed by HPT at room temperature is aged artificially at 120 and $170{ }^{\circ} \mathrm{C}$ for $2 \mathrm{~h}$. Then, the change of the microstructure and the phase composition due to the heat treatments are studied by X-ray diffraction (XRD) and transmission electron microscopy (TEM). In addition, the hardness evolution during aging is investigated, and correlated to the changes in the dislocation density and the precipitates. The thermal stability of the HPTprocessed disk is compared with the results obtained recently on an ECAP-processed alloy with the same composition [25]. It is noted that the temperature and time of aging in this study were selected to agree with the conditions often applied for the homogenization of the undeformed counterparts of $\mathrm{Al}$ $4.8 \% \mathrm{Zn}-1.2 \% \mathrm{Mg}-0.14 \% \mathrm{Zr}$ alloy $[4,25]$. Therefore, the present results may be interesting not only for basic research but also in practical applications.

\section{Materials and methods}

\section{Processing of the samples}

The alloy with the composition of Al-4.8\% Zn$1.2 \% \mathrm{Mg}-0.14 \% \mathrm{Zr}$ (wt \%) was processed by casting. The composition of the as-cast sample was determined by using the conventional optical emission spectroscopy (OES) analytical method. The as-cast material was homogenized in air at $470{ }^{\circ} \mathrm{C}$ for $8 \mathrm{~h}$, and then hot extruded at $380{ }^{\circ} \mathrm{C}$. Then, disks with a diameter of $20 \mathrm{~mm}$ and a thickness of $1.4 \mathrm{~mm}$ were cut from the extruded rods for processing by HPT. Before HPT processing, the alloy was homogenized 

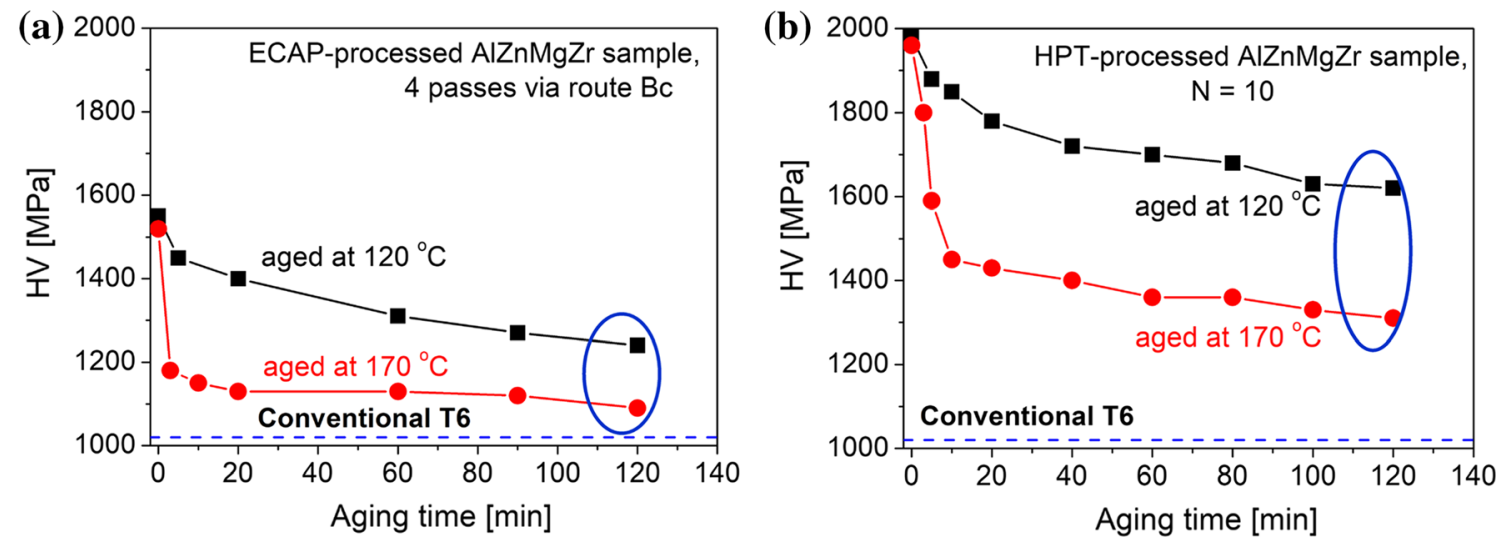

Figure 1 Hardness as a function of aging time at 120 and $170{ }^{\circ} \mathrm{C}$ for the samples processed by 4 passes of ECAP (a) and 10 turns of HPT (b). The blue ellipses indicate the studied states (aging for $2 \mathrm{~h}$ ).

and recrystallized at $470{ }^{\circ} \mathrm{C}$ for $1 \mathrm{~h}$ and then waterquenched to RT. The microstructure of the homogenized sample has been shown and discussed in a previous paper [25]. Considering literature experiences [26-29], the disks were subjected to $N=10$ turns of HPT at RT under a pressure of $6 \mathrm{GPa}$ and at a rotation speed of $1 \mathrm{rpm}$. The thickness $(h)$ of the disk after HPT process was $\sim 1.3 \mathrm{~mm}$. The equivalent strain, $\varepsilon_{e q}$ imposed by HPT at the radial distance $r$ from the disk center, can be given by the wellestablished formula [30]:

$\varepsilon_{e q}=\frac{2 \pi N r}{h \sqrt{3}}$.

It should be noted that according to Eq. (1), the equivalent strain has a radial dependence. Earlier experimental data [26-29] have shown that this radial dependence leads to inhomogeneity in both microstructure and hardness at low numbers of HPT turns, typically for $N<5$. For higher numbers of $N$ performed at high pressures the microstructure and the hardness for polycrystalline metal samples become reasonably homogeneous along the disk radius. Therefore, we chose 10 turns in order to get a high degree of homogeneity which was checked by hardness measurements at least along two diameters for each HPT-processed disk. Five disks were processed by HPT. Then, these samples were used for annealing and the characterization of the microstructure and hardness.

The disks processed by HPT were stored at RT for a long period (about 3 months) and then artificially aged at $120{ }^{\circ} \mathrm{C}$ or $170{ }^{\circ} \mathrm{C}$ for $2 \mathrm{~h}$ in an oil bath. Considering the fact that in the case of conventional supersaturated AlZnMg alloys stored at room temperature, the formation of Guinier-Preston (GP) zones occurs in the first month following quenching; therefore for longer times the microstructure (and thus the hardness) can be regarded as quasi-stable. In the present case, the sample transportation between the research groups and the surface preparation for the different investigations required a time period of about 3 months after HPT processing. The effect of aging on the microstructure and hardness was studied at the half-radius of the HPT-processed disk where the equivalent strain was $\sim 150$.

\section{Microstructure characterization techniques}

The phase composition and the microstructure of the HPT-processed and the aged specimens were studied by X-ray diffraction (XRD). The diffraction patterns were taken by a rotating anode diffractometer (type: MultiMax-9, manufacturer: Rigaku, Japan) using $\mathrm{CuK} \alpha_{1}$ radiation (wavelength: $\lambda=0.15,406 \mathrm{~nm}$ ). The diffraction domain size and the dislocation density in the $\mathrm{Al}$ matrix were determined by X-ray line profile analysis (XLPA) of the diffraction patterns. This analysis was performed by the Convolutional Multiple Whole Profile (CMWP) fitting method [31]. In this procedure, the experimental diffraction pattern is fitted by the sum of a background spline and the theoretical peak profiles calculated for each reflection. These theoretical peaks were obtained as the convolution of the measured instrumental reflection and the line profiles related to the diffraction domain size and the dislocations. The instrumental pattern was measured on a $\mathrm{LaB}_{6}$ line profile standard material. The area-weighted mean diffraction domain size 
$\left.(<x\rangle_{\text {area }}\right)$ and the average dislocation density $(\rho)$ were determined from the line profile fitting. The area-weighted mean diffraction domain size was calculated as $\langle x\rangle_{\text {area }}=m \cdot \exp \left(2.5 \sigma^{2}\right)$, where $m$ is the median and $\sigma^{2}$ is the log-normal variance of the diffraction domain size distribution.

The size and morphology of the matrix grains and the precipitates at the half-radius of the HPT-processed sample ( $\sim 5 \mathrm{~mm}$ from the disk center) were characterized by transmission electron microscopy (TEM). Thin TEM foils were prepared by mechanical polishing in the first step and then thinned to perforation at $-20{ }^{\circ} \mathrm{C}$ using a twin-jet electropolishing unit with a chemical solution containing $33 \% \mathrm{HNO}_{3}$ and $67 \% \mathrm{CH}_{3} \mathrm{OH}$. The TEM images characterize the microstructure in the plane of the HPT disk.

A Titan Themis G2 200 scanning transmission electron microscope (STEM) was used for TEM and energy-disperse X-ray spectroscopy (EDS) investigations. The microscope was equipped with a foursegment Super-X EDS detector. A corrector for the spherical aberration $\left(\mathrm{C}_{\mathrm{s}}\right)$ was applied at the imaging part, while no probe-correction was present. The image resolution is $0.16 \mathrm{~nm}$ in STEM Z-contrast imaging mode (recorded with a Fishione high-angle annular dark-field (HAADF) detector). The EDS data were recorded (together with the HAADF signal) in spectrum-image mode, and elemental maps were made for the constituents of the alloy in order to study the size and morphology of the different precipitates. The grain size was determined by measuring the diameters of the grains visible on the TEM images. About fifty grains were evaluated for each sample and the average of the grain size was calculated. The uncertainty of the grain size values was about $10 \%$.

\section{Hardness testing}

A Zwick Roell $\mathrm{ZH} \mu$ hardness tester was used for the measurement of the Vickers microhardness of the samples. The experiments were performed at RT using an applied load of $500 \mathrm{~g}$ and a dwell time of $10 \mathrm{~s}$. The average hardness values were calculated from at least 10 individual measurements, with a relative error lower than 3\%. In the present work, the hardness is given in the unit of MPa. The hardness in $\mathrm{MPa}$ can be obtained by multiplying HV number with the constant of 9.81 .

\section{Experimental results}

\section{XRD characterization of the phase composition and the microstructure of the HPT-processed and the aged alloys}

Figure 2a shows the XRD diffraction pattern obtained for the HPT-processed sample. The intensity is plotted in logarithmic scale in order to reveal whether small peaks of secondary phases exist or not. It can be seen that only the diffraction peaks of the $\mathrm{Al}$ matrix appeared in the pattern. Aging at $120^{\circ} \mathrm{C}$ resulted in the development of a hexagonal $\eta-\mathrm{MgZn}_{2}$ phase (PDF card number: 34-0457) as revealed by the part of the diffraction pattern shown in Fig. 2b. Peaks of $\eta^{\prime}$ phase (PDF card number: 31-0024) were not observed by $\mathrm{XRD}$. The fraction of the $\eta-\mathrm{MgZn}_{2}$ was characterized by the intensity ratio of this phase in the XRD pattern. This quantity was determined as the ratio of the sum of the areas under the $\eta-\mathrm{MgZn}_{2}$ peaks and the sum of the areas under all peaks in the diffractogram in the diffraction angle range $2 \theta=30-150^{\circ}$. Table 1 shows the data determined by using X-ray diffraction. It can be seen that the XRD intensity percentage of $\eta-\mathrm{MgZn}_{2}$ phase was $5.0 \pm 0.5 \%$ for the sample aged at $120{ }^{\circ} \mathrm{C}$ which increased to $8.3 \pm 0.5 \%$ at $170{ }^{\circ} \mathrm{C}$.

The average diffraction domain size and the dislocation density were determined by XLPA. As an example, Fig. 3 shows the CMWP fitting on the diffraction pattern measured for the HPT sample. The domain size and the dislocation density obtained for the HPT-processed and the aged samples are also listed in Table 1. In the HPT specimen, the diffraction domain size was $54 \pm 6 \mathrm{~nm}$ while the dislocation density was $(8.0 \pm 0.9) \times 10^{14} \mathrm{~m}^{-2}$. After aging at $120^{\circ} \mathrm{C}$ and $170{ }^{\circ} \mathrm{C}$, the domain size increased to $73 \pm 8 \mathrm{~nm}$ and $111 \pm 12 \mathrm{~nm}$, respectively. The dislocation density decreased from $(8.0 \pm 0.9) \times 10^{14} \mathrm{~m}^{-2}$ to $(2.6 \pm 0.3) \times 10^{14} \mathrm{~m}^{-2}$ when the HPT-processed sample was aged at $120^{\circ} \mathrm{C}$. During aging at $170{ }^{\circ} \mathrm{C}$, the dislocation density decreased to a lower value of $(0.4 \pm 0.1) \times 10^{14} \mathrm{~m}^{-2}$.

\section{TEM study of the microstructure}

Figure 4 shows bright-field TEM images taken on the sample processed by HPT and the specimens subsequently aged at $120{ }^{\circ} \mathrm{C}$ and $170{ }^{\circ} \mathrm{C}$. The evaluation of numerous bright- and dark-field TEM images 
(a)

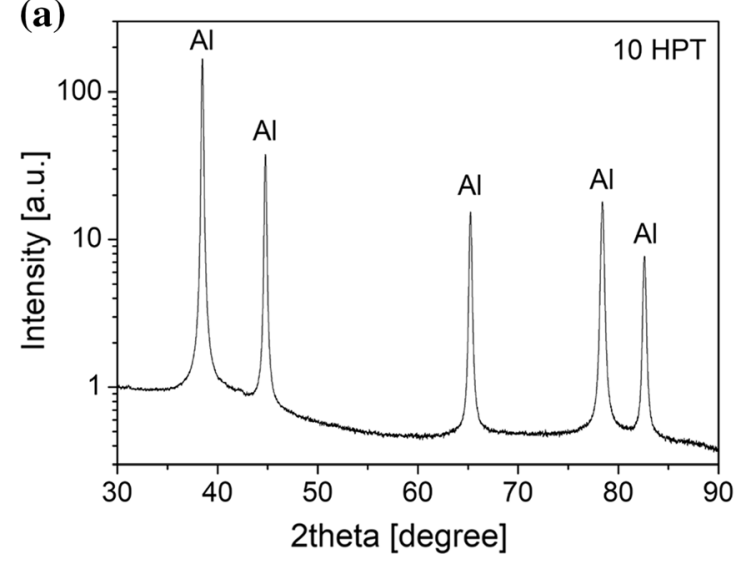

(b) 10

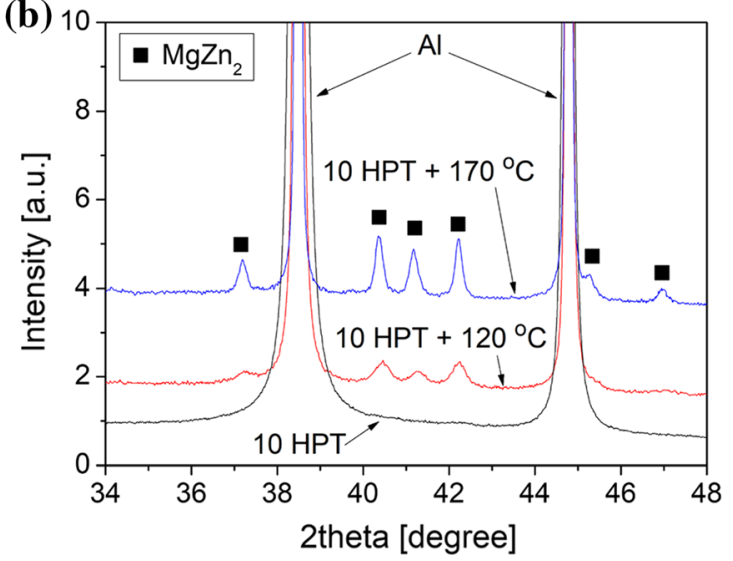

Figure 2 a XRD pattern for the HPT-processed sample in logarithmic intensity scale. $\mathbf{b}$ A part of the XRD patterns in linear intensity scale measured on the HPT-processed sample and the specimens aged at 120 and $170{ }^{\circ} \mathrm{C}$ for $2 \mathrm{~h}$.

Table 1 The XRD intensity percentage of $\eta-\mathrm{MgZn}_{2}$ precipitates as well as the diffraction domain size and the dislocation density of the Al matrix as determined by XLPA for the HPT-processed sample and the subsequently aged specimens

\begin{tabular}{lccc}
\hline Sample & $\begin{array}{l}\text { Intensity percentage of } \mathrm{MgZn}_{2} \\
(\%)\end{array}$ & $\begin{array}{l}\text { Diffraction domain size in the matrix } \\
(\mathrm{nm})\end{array}$ & $\begin{array}{l}\text { Dislocation density in the matrix } \\
\left(10^{14} \mathrm{~m}^{-2}\right)\end{array}$ \\
\hline $\begin{array}{l}10 \mathrm{HPT} \text { at RT } \\
10 \mathrm{HPT}+\text { aged at }\end{array}$ & $5.0 \pm 0.5$ & $54 \pm 6$ & $8.0 \pm 0.9$ \\
$120{ }^{\circ} \mathrm{C}$ & $73 \pm 8$ & $0.4 \pm 0.1$ \\
$10 \mathrm{HPT}+$ aged at & $8.3 \pm 0.5$ & $111 \pm 12$ & $4.8 \pm 0.5$ \\
$170{ }^{\circ} \mathrm{C}$ & & $92 \pm 10$ & $5.0 \pm 0.5$ \\
$4 \mathrm{ECAP}$ at RT & $0.9 \pm 0.2$ & $105 \pm 11$ & $3.3 \pm 0.4$ \\
$4 \mathrm{ECAP}+$ aged at & $0.9 \pm 0.2$ & & \\
$120{ }^{\circ} \mathrm{C}$ & $6.8 \pm 0.9$ & $111 \pm 12$ & \\
$4 \mathrm{ECAP}+$ aged at & & & \\
$170{ }^{\circ} \mathrm{C}$ & & & \\
\hline
\end{tabular}

For comparison, the microstructural parameters obtained for an ECAP-processed sample aged under the same conditions are also listed (the data were taken from Ref. [25])

yielded $\sim 200 \mathrm{~nm}$ for the average grain size for the HPT-processed alloy. It can also be seen that aging at $120{ }^{\circ} \mathrm{C}$ did not lead to significant grain coarsening while at $170{ }^{\circ} \mathrm{C}$ the grain size increased to about $360 \mathrm{~nm}$ (see Table 2). It should be noted that the grain size values determined by the present TEM study are larger with a factor of 3-4 than the diffraction domain sizes obtained by XLPA (compare Tables 1 and 2). This difference has already been observed for other SPD-processed samples and can be explained by the hierarchical microstructure of the investigated materials [32]. Namely, X-ray diffraction is very sensitive to small misorientations; therefore, the domain size determined by XLPA reflects rather the size of subgrains which is certainly lower than the grain size determined by TEM. Figure $4 \mathrm{~b}$ shows dislocations inside a grain of the HPT-processed sample. The average spacing of dislocations is about $50 \mathrm{~nm}$ which suggests that the dislocation density has an order of magnitude $10^{14} \mathrm{~m}^{-2}$ in accordance with the results of XLPA (see the previous section). However, the changes of the dislocation density during aging were not studied directly by TEM since this method investigates only a very small volume compared to XLPA. Therefore, the quantitative characterization of the dislocation density by XLPA is more reliable than by TEM.

The evolution of precipitates during aging was studied using HAADF images and EDS maps taken by the Titan Themis STEM. Figure 5a shows a 


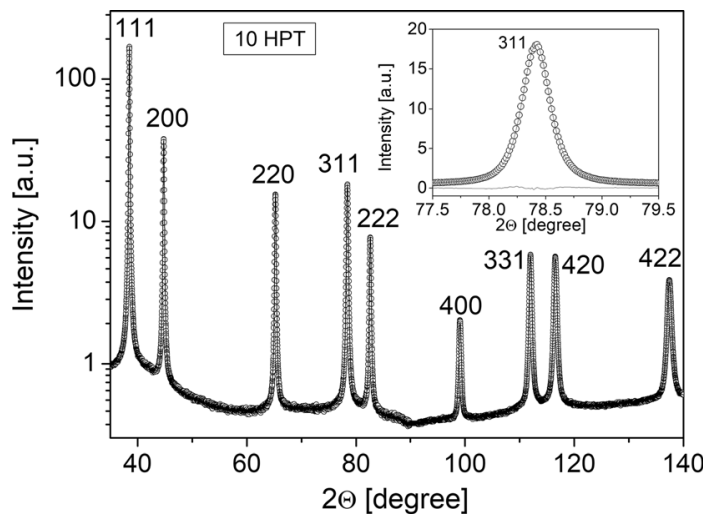

Figure 3 The measured XRD pattern (open circles) and the diffractogram fitted by the CMWP method (solid line) for the HPT-processed specimen. In order to a better visibility of the fitting quality, the inset shows the magnified reflection 311 . The difference between the measured and fitted data can be seen at the bottom of the inset.

HAADF image that reveals only few precipitates in the grain boundaries (indicated by bright contrast as these precipitates must contain elements heavier than $\mathrm{Al}$, e.g., $\mathrm{Zn}$ and/or $\mathrm{Zr}$ ). The HAADF image in Fig. $5 \mathrm{~b}$ shows that there are precipitates not only in the boundaries but also in the grain interiors. The corresponding EDS elemental maps for the main constituents ( $\mathrm{Al}, \mathrm{Zn}, \mathrm{Mg}$ and $\mathrm{Zr}$ ) are presented in Fig. $5 \mathrm{c}-$ $\mathrm{f}$. These maps reveal that there are $\mathrm{Mg} / \mathrm{Zn}$-rich and Zr-rich precipitates in the HPT-processed sample even if diffraction peaks of secondary phases did not appear in the XRD patterns. This apparent contradiction can be explained by the very low concentration of $\mathrm{Zr}$ which suggests only a low amount of $\mathrm{Zr}$ rich precipitates. EDS element analysis revealed that these $\mathrm{Zr}$-rich precipitates are $\mathrm{Al}_{3} \mathrm{Zr}_{0.7} \mathrm{Zn}_{0.3}$ particles in accordance with former studies (e.g., [33]). These $\mathrm{Al}_{3} \mathrm{Zr}_{0.7} \mathrm{Zn}_{0.3}$ precipitates pin effectively the grain boundaries, thereby resulting in a better thermal stability of the UFG microstructure [34, 35]. Therefore, the X-ray intensity scattered by these particles was so weak that it cannot be detected in the XRD pattern. Concerning the $\mathrm{Mg} / \mathrm{Zn}$-rich precipitates,
Figure 4 TEM images showing the microstructure for the HPT-processed sample (a, b) and the specimens subsequently annealed at 120 (c) and $170{ }^{\circ} \mathrm{C}$ (d). In figure (b), some dislocations are visible inside a grain as indicated by black arrows. The TEM images characterize the microstructure in the plane of the HPT disk.
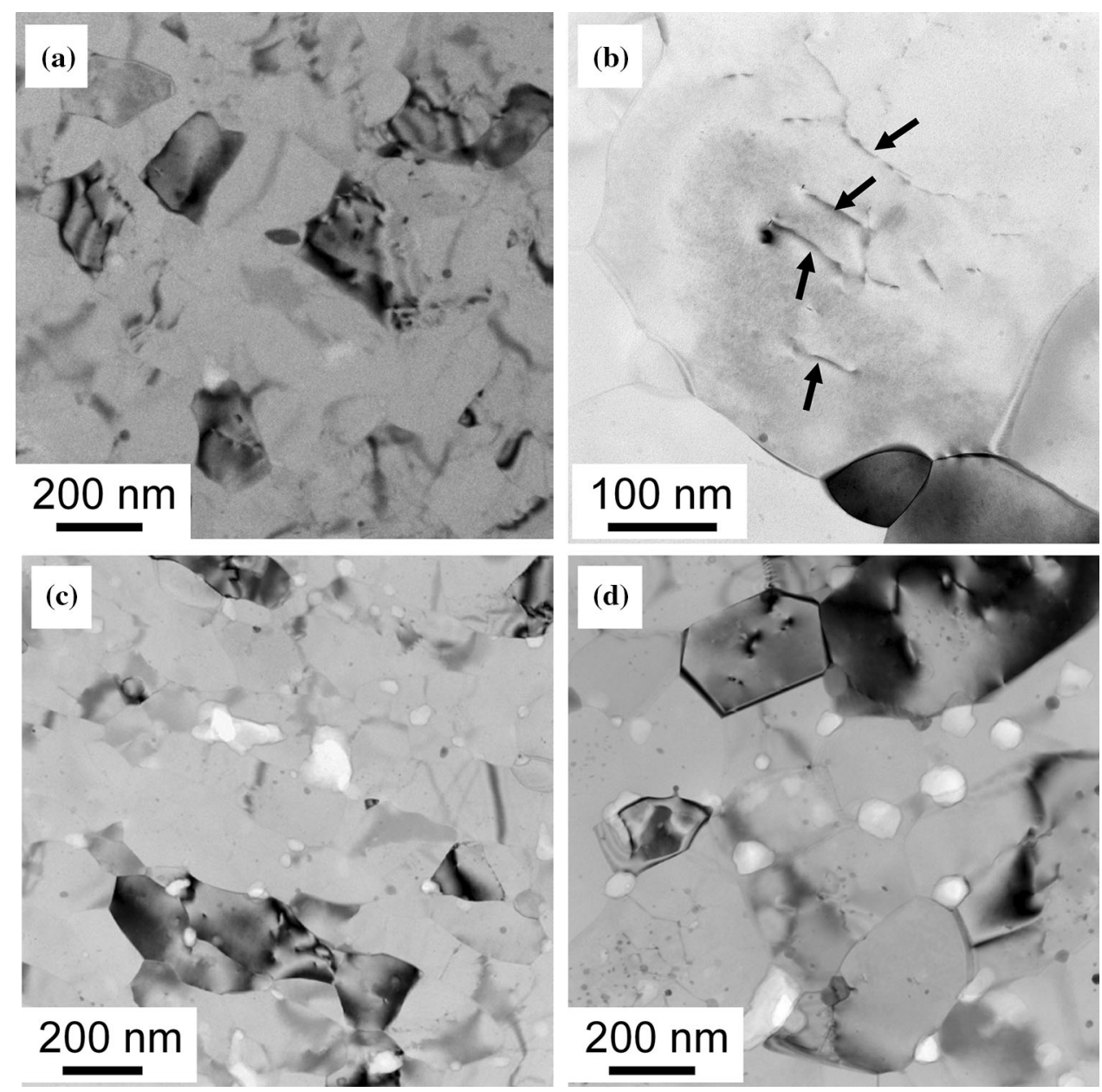
Table 2 The average grain size in the Al matrix determined from TEM images and the average particle size of the $\mathrm{Mg} / \mathrm{Zn}$-rich and $\mathrm{Zr}$-rich precipitates as obtained from the HAADF images and the EDS maps

\begin{tabular}{lllll}
\hline Sample & $\begin{array}{l}\text { Grain size in the Al matrix } \\
(\mathrm{nm})\end{array}$ & $\begin{array}{l}\text { Particle size, Mg/Zn-rich } \\
(\mathrm{nm})\end{array}$ & $\begin{array}{l}\text { Particle size, Zr-rich } \\
(\mathrm{nm})\end{array}$ & $\begin{array}{l}\text { Diffraction domain size, } \\
\mathrm{MgZn}_{2}(\mathrm{~nm})\end{array}$ \\
\hline $10 \mathrm{HPT}$ at RT & 200 & $10(2-20)$ & $15(10-20)$ & - \\
$10 \mathrm{HPT}+120{ }^{\circ} \mathrm{C}$ & 200 & $25(4-60)$ & $20(10-30)$ & 25 \\
$10 \mathrm{HPT}+170{ }^{\circ} \mathrm{C}$ & 360 & $40(5-70)$ & $25(15-30)$ & 45 \\
$4 \mathrm{ECAP}$ at RT & 260 & $15(2-20)$ & Not found & 30 \\
$4 \mathrm{ECAP}+$ aged at & 310 & $30(3-60)$ & Not found & 40 \\
$120{ }^{\circ} \mathrm{C}$ & & $50(5-100)$ & & \\
$4 \mathrm{ECAP}+$ aged at & 530 & & & \\
$170{ }^{\circ} \mathrm{C}$ & & &
\end{tabular}

The range of particle sizes for the precipitates is shown in the parentheses. The average diffraction domain size values for the $\mathrm{MgZn}_{2}$ phase calculated from the XRD peak width are also listed. For comparison, the microstructural parameters obtained for an ECAP-processed sample aged under the same conditions are also listed (the data were taken from Ref. [25])
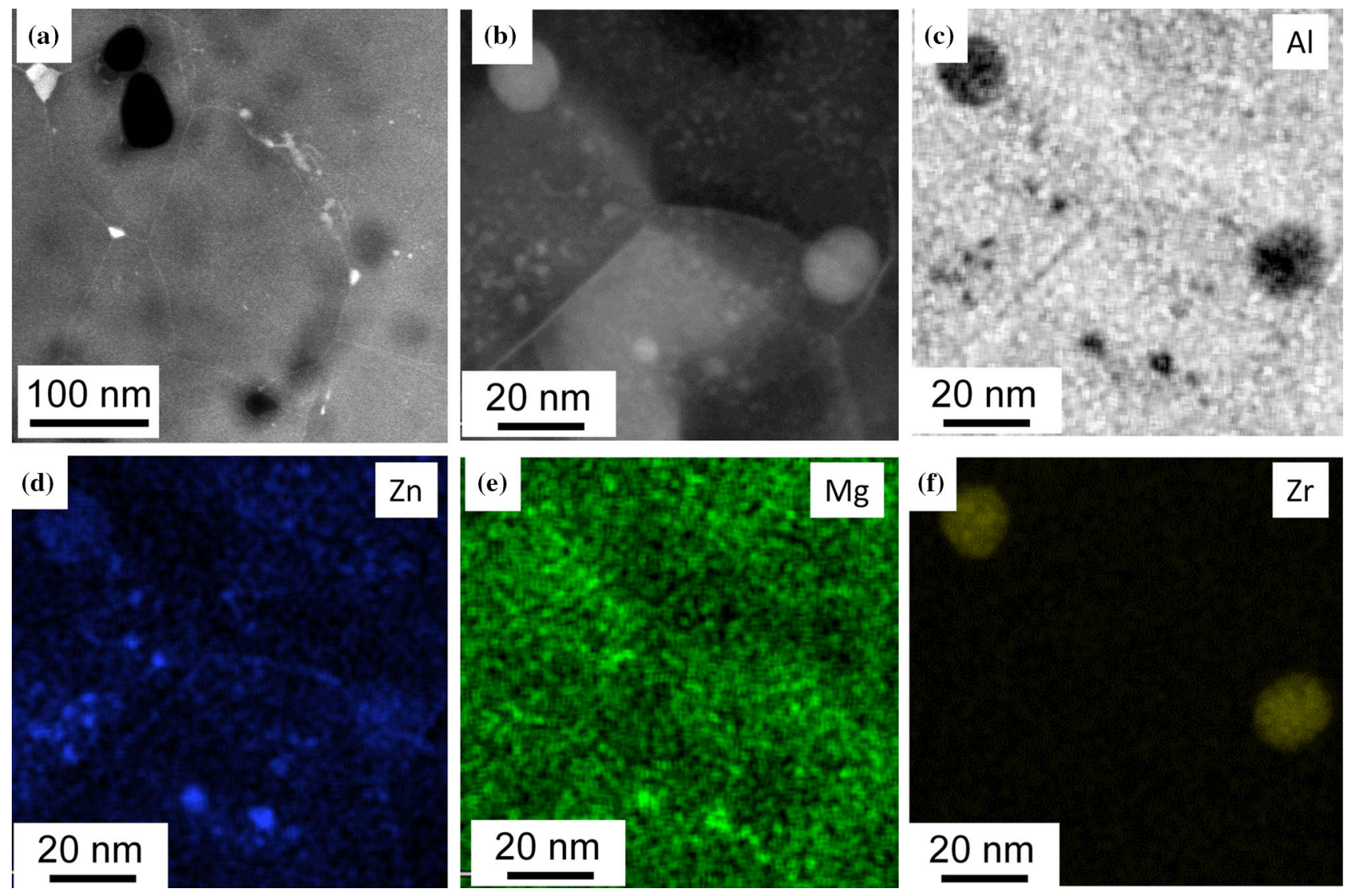

Figure 5 (a, b) HAADF STEM images illustrating the microstructure of the HPT-processed sample. (c-f) EDS elemental maps for Al, $\mathrm{Zn}, \mathrm{Mg}$ and $\mathrm{Zr}$ obtained on the area shown in (b). The TEM images characterize the microstructure in the plane of the HPT disk.

although they have a relatively large amount inside the grains as indicated by HAADF and EDS images, their diffraction peaks also cannot be detected in the XRD pattern of the HPT sample. This observation suggests that the very small $\mathrm{Mg} / \mathrm{Zn}$-rich precipitates (typical size: $2 \mathrm{~nm}$ ) are Guinier-Preston (GP) zones which are enriched with $\mathrm{Mg}$ and $\mathrm{Zn}[19,20]$. These GP zones are formed during HPT-processing and 
after storage of the samples at RT. From the evaluation of many HAADF images and EDS maps, the size of $\mathrm{Mg} / \mathrm{Zn}$-rich precipitates in the grain interiors ranged between 2 and $10 \mathrm{~nm}$ while in the grain boundaries their size varied between 10 and $20 \mathrm{~nm}$. The average size of $\mathrm{Mg} / \mathrm{Zn}$-rich precipitates in the whole sample was $\sim 10 \mathrm{~nm}$ (see Table 2). The diameter of the $\mathrm{Zr}$-rich particles can be found in the range of 10-20 nm with an average value of $15 \mathrm{~nm}$.

The HAADF images in Fig. 6a and b show the precipitates in the HPT sample aged at $120{ }^{\circ} \mathrm{C}$. The EDS maps corresponding to Fig. $6 \mathrm{~b}$ are presented in Fig. $6 \mathrm{c}-\mathrm{f}$. In the grain interiors, the size of $\mathrm{Mg} / \mathrm{Zn}$ rich particles varied between 4 and $15 \mathrm{~nm}$ while in the grain boundaries their size was within the range of 20-60 nm. It can be concluded for both the $\mathrm{Mg} / \mathrm{Zn}-$ rich and the Zr-rich precipitates that their average sizes increased to 25 and $20 \mathrm{~nm}$, respectively, during aging at $120^{\circ} \mathrm{C}$ (see Table 2). The change of average size of Zr-rich particles has recently been observed also in the alloy $\mathrm{Al}-0.4 \% \mathrm{Zr}$ in the process of HPT. As was revealed in [36], such change was due to their dissolution during processing. For this aged sample, XRD peaks of the $\mathrm{MgZn}_{2}$ phase appeared on the diffraction pattern, and the average domain size for this phase was determined from the width of the peak detected at the diffraction angle of about $40.4^{\circ}$ (see Fig. $2 b)$. The obtained value $(\sim 25 \mathrm{~nm})$ is in agreement with the average particle size obtained from the HAADF and EDS images (see Table 2). This result suggests that a significant amount of $\mathrm{Mg} / \mathrm{Zn}$ rich particles has $\eta-\mathrm{MgZn}_{2}$ structure which is also supported by the relatively high intensity percentage of $\eta-\mathrm{MgZn}_{2}$ phase $(\sim 5 \%$, see Table 1$)$. Thus, it can be concluded that aging at $120{ }^{\circ} \mathrm{C}$ for $2 \mathrm{~h}$ resulted in a transition from GP zones to $\eta-\mathrm{MgZn}_{2}$ precipitates.

Aging at $170{ }^{\circ} \mathrm{C}$ resulted in further coarsening of the precipitates as shown in the HAADF images of Figs. $7 a$ and $b$. The EDS maps corresponding to Fig. $7 \mathrm{~b}$ are presented in Figs. $7 \mathrm{c}-\mathrm{f}$. It is revealed that the average size of $\mathrm{Mg} / \mathrm{Zn}$-rich and $\mathrm{Zr}$-rich particles increased to $\sim 40$ and $\sim 25 \mathrm{~nm}$, respectively, as shown in Table 2. Inside the grains, the size of precipitates is still lower $(5-30 \mathrm{~nm})$ than that in the grain boundaries $(30-70 \mathrm{~nm})$. The average diffraction domain size of the $\eta-\mathrm{MgZn}_{2}$ phase $(\sim 45 \mathrm{~nm})$ was close to the average size of the $\mathrm{Mg} / \mathrm{Zn}$-rich particles $(\sim 40 \mathrm{~nm}$ ) determined from HAADF and EDS, suggesting that the majority of these precipitates has $\eta$ $\mathrm{MgZn}_{2}$ structure, in accordance with the high intensity percentage of this phase $(\sim 8.3 \%)$ in the diffraction pattern. It seems that the higher aging temperature yielded a more pronounced evolution of $\eta-\mathrm{MgZn}_{2}$ phase from the GP zones and an additional precipitate coarsening.

\section{Hardness of the HPT-processed and the aged specimens}

The microhardness of the HPT-processed sample was $1970 \pm 60 \mathrm{MPa}$. The hardness value decreased to $1620 \pm 50 \mathrm{MPa}$ and $1310 \pm 30 \mathrm{MPa}$ after aging at $120^{\circ} \mathrm{C}$ and $170{ }^{\circ} \mathrm{C}$, respectively. The reduction of hardness can be attributed to the decrease in the dislocation density and/or the changes in the precipitate structure during annealing as discussed in the next section.

\section{Discussion}

\section{Correlation between the microstructure and the hardness}

The obtained results provide evidence that HPT leads to significant microstructural changes in the alloy, where the formation of ultrafine grains is accompanied by the appearance of nanosized precipitates of secondary phases- $\mathrm{Mg} / \mathrm{Zn}$-rich and Zn-rich particles. These microstructural features markedly differ from those observed in conventional coarse-grained counterpart [25]. Moreover, recent observations on fine structure in HPT-processed Al alloys by means of precise atom probe tomography [37] made it possible to establish the formation of considerable segregations of $\mathrm{Mg}$ and $\mathrm{Zn}$ at grain boundaries, which may also have an effect on the mechanical properties, especially at high temperatures.

The decrease in the hardness due to aging can be attributed at least partly to the reduction of the dislocation density (see Table 1). The contribution of dislocation strengthening to the hardness $\left(H V_{\text {disl }}\right)$ can be calculated from the Taylor equation as:

$H V_{\text {disl }}=3 \alpha M^{T} G b \rho^{1 / 2}$.

The factor of three standing in the beginning of the right-hand side of this formula is used for taking the ratio of the hardness and the yield strength into account [38]. Moreover, in eq. (2) $\alpha$ describes the dislocation strengthening (about 0.32 for $\mathrm{Al}$ [39]), $G$ is 

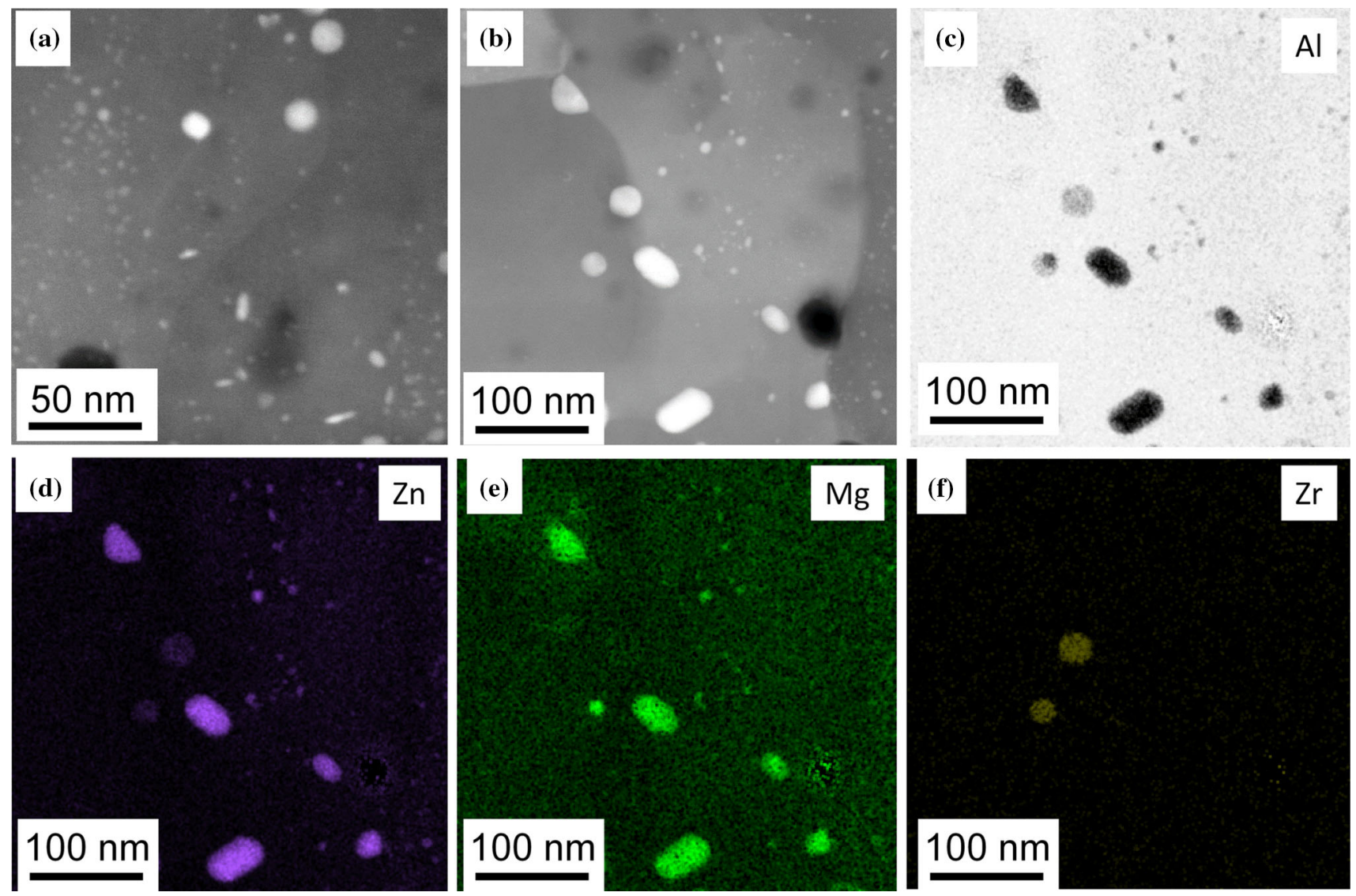

Figure 6 (a, b) HAADF STEM images illustrating the microstructure of the specimen processed by HPT and then aged at $120{ }^{\circ} \mathrm{C}$ for $2 \mathrm{~h}$. (c-f) EDS elemental maps for $\mathrm{Al}, \mathrm{Zn}, \mathrm{Mg}$ and

the shear modulus ( $\sim 26 \mathrm{GPa}$ for $\mathrm{Al}$ ), $b$ is the magnitude of the Burgers vector $(\sim 0.287 \mathrm{~nm}$ for $\mathrm{Al})$, and $M^{T}$ is the Taylor factor. Due to the lack of strong texture, $M^{T}$ was taken as 3.06. The values of $H V_{\text {disl }}$ calculated from the Taylor equation for the HPTprocessed sample and the aged specimens are listed in Table 3. Immediately after HPT, the hardness caused by the dislocation was $620 \pm 60 \mathrm{MPa}$ which is $31 \%$ of the total hardness value. Due to the reduction of the dislocation density during aging at $120^{\circ} \mathrm{C}$ and $170{ }^{\circ} \mathrm{C}$ the value of $H V_{\text {disl }}$ decreased to $350 \pm 40 \mathrm{MPa}$ and $140 \pm 20 \mathrm{MPa}$, respectively. These values represent $21 \%$ and $11 \%$ of the total hardness for $120^{\circ} \mathrm{C}$ and $170{ }^{\circ} \mathrm{C}$, respectively, i.e., the contribution of dislocations to hardness decreased with increasing the aging temperature.

As was established in numerous works $[1,37,40,41]$ the contribution of grain boundaries to the yield stress and ultimate tensile strength in the UFG materials processed by SPD techniques is quite
$\mathrm{Zr}$ obtained on the area shown in (b). The TEM images characterize the microstructure in the plane of the HPT disk.

considerable. According to the well-known HallPetch relationship, the strengthening contribution of the grain size can be written as:

$H V_{G S}=K_{H} d^{-1 / 2}$,

where $d$ is the grain size and $K_{\mathrm{H}}$ is an appropriate constant associated with the hardness measurements. The value of $K_{\mathrm{H}}\left(210 \mathrm{MPa} \mu \mathrm{m}^{1 / 2}\right)$ was taken from [42], in which the Hall-Petch equation was investigated for a wide range of grain size in pure $\mathrm{Al}$. The contribution of the grain size to the hardness for the HPT-processed and the aged specimens is shown in Table 3. It can be seen that after HPT, the hardness, $H V_{G S}$ caused by the Hall-Petch effect was $\sim 470$ $\mathrm{MPa}$ which is about $24 \%$ of the total hardness value. During aging at $120{ }^{\circ} \mathrm{C}$, the value of $H V_{G S}$ did not change, as the grain size remained unchanged, but for aging at $170{ }^{\circ} \mathrm{C}$ the value of $H V_{G S}$ decreased to $\sim 350 \mathrm{MPa}$, correspondingly to the grain-growth at this temperature. 

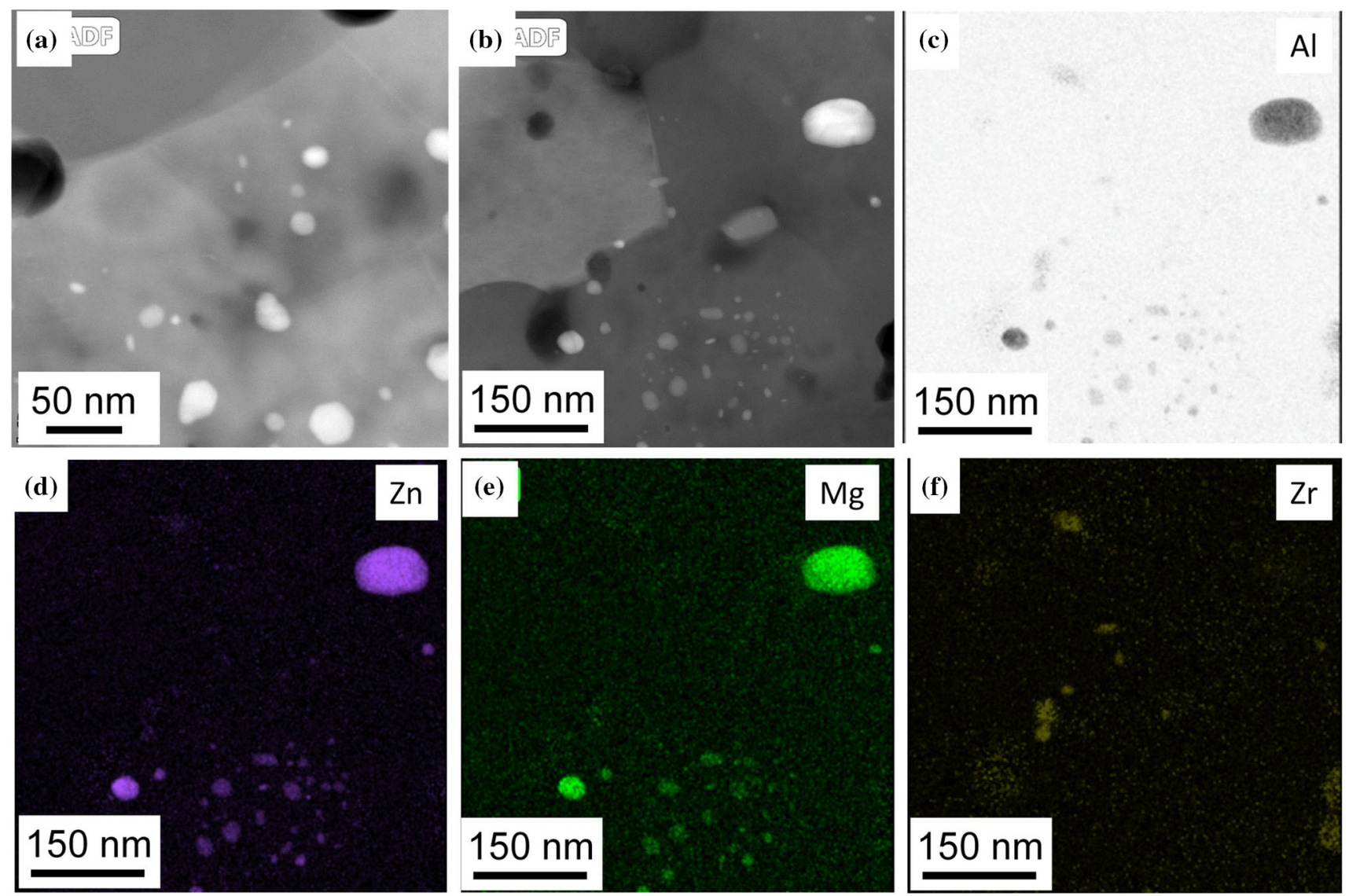

Figure 7 (a, b) HAADF STEM image illustrating the microstructure of the specimen processed by HPT and then aged $\mathrm{Zr}$ obtained on the area shown in (b). The TEM images characterize the microstructure in the plane of the HPT disk. at $170{ }^{\circ} \mathrm{C}$ for $2 \mathrm{~h}$. (c-f) EDS elemental maps for $\mathrm{Al}, \mathrm{Zn}, \mathrm{Mg}$ and

Table 3 The total measured microhardness $\left(\mathrm{HV}_{\text {total }}\right)$, and the calculated contributions of the lattice friction $\left(\mathrm{HV}_{0}\right)$, dislocations $\left(\mathrm{HV}_{\mathrm{disl}}\right)$, grain size $\left(\mathrm{HV}_{\mathrm{GS}}\right)$ and precipitates $\left(\mathrm{HV}_{\text {precip }}\right)$

\begin{tabular}{llllll}
\hline Sample & $\mathrm{HV}_{\text {total }}(\mathrm{MPa})$ & $\mathrm{HV}_{0}(\mathrm{MPa})$ & $\mathrm{HV}_{\text {disl }}(\mathrm{MPa})$ & $\mathrm{HV}_{\mathrm{GS}}(\mathrm{MPa})$ & $\mathrm{HV}$ precip $(\mathrm{MPa})$ \\
\hline $10 \mathrm{HPT}$ at RT & $1970 \pm 60$ & $60 \pm 10$ & $620 \pm 60$ & $\sim 470$ & $820 \pm 130$ \\
$10 \mathrm{HPT}+$ aged at $120^{\circ} \mathrm{C}$ & $1620 \pm 50$ & $60 \pm 10$ & $350 \pm 40$ & $\sim 470$ & $740 \pm 100$ \\
$10 \mathrm{HPT}+$ aged at $170{ }^{\circ} \mathrm{C}$ & $1310 \pm 30$ & $60 \pm 10$ & $140 \pm 20$ & $\sim 350$ & $760 \pm 60$ \\
4 ECAP at RT & $1470 \pm 40$ & $60 \pm 10$ & $480 \pm 60$ & $\sim 410$ & $520 \pm 110$ \\
4 ECAP + aged at $120{ }^{\circ} \mathrm{C}$ & $1230 \pm 40$ & $60 \pm 10$ & $480 \pm 60$ & $\sim 380$ & $310 \pm 110$ \\
4 ECAP + aged at $170{ }^{\circ} \mathrm{C}$ & $1100 \pm 30$ & $60 \pm 10$ & $400 \pm 50$ & $\sim 290$ & $350 \pm 90$ \\
\hline
\end{tabular}

For the ECAP-processed and annealed samples, the hardness values were calculated from the microstructural parameters presented in Ref. [25]

The evolution of precipitates has also an impact on the change of the hardness during aging. Although the total concentration of alloying elements did not change during aging, they can appear in different forms in the matrix such as solute atoms, GP zones and $\eta-M g Z n_{2}$ precipitates. It is well known that the strengthening effects of these various structures may be significantly different [19-21]. For instance, the increase in the size of GP zones at constant volume fraction yields hardening since they can be cut by dislocations, while the coarsening of $\eta$ precipitates under similar conditions causes softening as they 
cannot be cut by dislocations. In the present study, the contribution of precipitates to hardness $\left(H V_{\text {precip }}\right)$ was calculated by subtracting the contributions of dislocations $\left(H V_{\text {disl }}\right)$, grain size $\left(H V_{G S}\right)$ and lattice friction $\left(H V_{0}\right)$ from the total measured hardness $\left(H V_{\text {total }}\right)$ :

$H V_{\text {precip }}=H V_{\text {total }}-\left(H V_{0}+H V_{\text {disl }}+H V_{G S}\right)$.

Table 3 shows the values of $H V_{\text {precip }}$ for the HPTprocessed and the aged specimens. After HPT, the hardness contribution of precipitates was $820 \pm 130 \mathrm{MPa}$ which were $740 \pm 100 \mathrm{MPa}$ and $760 \pm 60 \mathrm{MPa}$ after aging at $120^{\circ} \mathrm{C}$ and $170{ }^{\circ} \mathrm{C}$, respectively. These data suggest that the transformation of a part of GP zones to $\eta-\mathrm{MgZn}_{2}$ particles during aging at $120{ }^{\circ} \mathrm{C}$ did not yield significant reduction of hardness. This can be explained by the very moderate coarsening of the precipitates in the grain interiors at $120{ }^{\circ} \mathrm{C}$ (from $2-10 \mathrm{~nm}$ to $4-15 \mathrm{~nm}$ ), i.e., overaging did not occur even if a considerable fraction of $\eta$ phase was formed from the GP zones. In this regard, only the precipitates inside the grains act as obstacles against dislocation glide, therefore only their hardening effect should be considered here. The aging at $170{ }^{\circ} \mathrm{C}$ resulted in also a practically unchanged contribution of precipitates to the hardness compared to the HPT-processed sample (see Table 3). Although the particles inside the grains were coarsened from $4-15 \mathrm{~nm}$ to $5-30 \mathrm{~nm}$ when the aging temperature increased from 120 to $170{ }^{\circ} \mathrm{C}$, simultaneously the intensity percentage of $\eta-\mathrm{MgZn}_{2}$ phase increased from 5 to $8.3 \%$. The latter effect compensated partly the precipitate coarsening; therefore, almost the same contribution of precipitates to hardness was observed at $170{ }^{\circ} \mathrm{C}$ as compared to $120^{\circ} \mathrm{C}$.

\section{Comparison of aging effects in HPT- and ECAP-processed samples}

As it has been mentioned, in a recent publication [25] we investigated the aging behavior of ECAP-processed $\mathrm{Al}$ alloy with the same composition. The ECAP was performed through 4 passes using route $\mathrm{B}_{\mathrm{C}}$, and the aging was carried out at the same temperature as for the HPT specimen $\left(120\right.$ and $\left.170{ }^{\circ} \mathrm{C}\right)$. The dislocation density in the ECAP-processed sample was lower $\left(\sim 4.8 \times 10^{14} \mathrm{~m}^{-2}\right)$ than the value observed for the HPT disk $\left(\sim 8 \times 10^{14} \mathrm{~m}^{-2}\right)$. This difference can be explained by the higher plastic strain and pressure used in HPT processing. The high hydrostatic pressure hinders diffusion [43-45] which is the basic mechanism of dynamic recovery; therefore, the dislocation density was higher for HPT compared to ECAP. At the same time, during aging the decrease in the dislocation density was more pronounced for the HPT sample since the larger initial dislocation density yields a higher driving force of recovery during annealing and the diffusion is also faster at ambient pressure due to the higher amount of dislocations and grain boundaries compared to the ECAP specimen. Thus, in the latter sample the dislocation density decreased from $\sim 4.8 \times 10^{14} \mathrm{~m}^{-2}$ only to $\sim 3.3 \times 10^{14} \mathrm{~m}^{-2}$ at $170{ }^{\circ} \mathrm{C}$ while the aging for the HPT disk yielded a much larger reduction in the dislocation density from $\sim 8 \times 10^{14} \mathrm{~m}^{-2}$ only to $\sim 0.4 \times 10^{14} \mathrm{~m}^{-2}$.

In the as-processed state, the ECAP sample contained $\eta-\mathrm{MgZn}_{2}$ phase besides GP zones while there were only GP zones in the HPT-processed specimen, i.e., the evolution of precipitates was faster during ECAP-processing. The formation of stable $\eta-\mathrm{MgZn}_{2}$ precipitates in a supersaturated $\mathrm{Al}$ solid solution requires diffusion. The atomic migration is faster along the grain boundaries than in the grain interiors; therefore, the particles of the $\eta-\mathrm{MgZn}_{2}$ phase formed mainly in the grain boundaries of the ECAP-processed sample. On the other hand, the high pressure applied in HPT processing hindered the diffusion in both the grain interiors and the grain boundaries, therefore fewer $\eta-\mathrm{MgZn}_{2}$ precipitates developed in the grain boundaries of the HPT sample, and only GP zones were observed after HPT. When the HPTprocessed sample was annealed at $120^{\circ} \mathrm{C}$ and $170{ }^{\circ} \mathrm{C}$, the high amount of grain boundaries and dislocations yielded a higher diffusion rate, resulting in a fast development of $\eta-\mathrm{MgZn}_{2}$ precipitates. Indeed, the intensity percentage of $\eta$ phase for the HPT sample was much higher than that for the ECAP specimen at both temperatures: for the ECAP samples $0.9 \%$ and $6.8 \%$ were detected at $120{ }^{\circ} \mathrm{C}$ and $170{ }^{\circ} \mathrm{C}$, respectively, while these values for the HPT disk were 5.0\% and $8.3 \%$. It should be noted that SPD can produce an enormous amount of vacancies in the $\mathrm{Al}$ matrix as shown in former studies [46-50], which dramatically influences the diffusion, and subsequently may enhance the precipitation process. For HPT, although the applied high pressure impeded the vacancy migration during processing, however when the 
pressure was released and the samples were annealed, the mobilized vacancies may contribute to the development of precipitates.

Considering the dislocation densities and grain sizes obtained previously for ECAP-processed samples [25], the contributions of different factors to hardness are recalculated by using Eqs. (2-4), and also listed in Table 3. It can be seen that the hardness of the HPT-processed disk was much higher ( $1970 \mathrm{MPa}$ ) than that for the ECAP specimen ( $1470 \mathrm{MPa}$ ). This difference can be explained by the higher dislocation density, smaller grain size and the less developed precipitates in the HPT disk. Namely, in the ECAP sample many large precipitates (most probably $\eta$ particles) can be found in the grain boundaries which developed due to the accelerated diffusion along the grain boundaries during ECAP. However, these particles do not contribute to hardening as they do not act as obstacles against the dislocation glide in the grain interiors. As an example, the HAADF image in Fig. 8a shows many particles in the grain boundaries of the ECAP-processed specimen. At the same time, in the HPT specimen only a very few particles can be found at the grain boundaries and the majority of precipitates are hard GP zones (see Fig. 5a). Therefore, the contribution of precipitates to the hardness $\left(H V_{\text {precip }}\right)$ is much higher for the HPT sample $(\sim 820 \mathrm{MPa})$ than that for the ECAP specimen $(\sim 520 \mathrm{MPa})$. This difference remained valid even after aging. Figure $8 b$ and $c$ shows HAADF images for the ECAP sample aged at $120^{\circ} \mathrm{C}$ and $170{ }^{\circ} \mathrm{C}$, respectively. Numerous coarse precipitates can be seen in the grain boundaries which do not contribute to hardening. Therefore, the hardness caused by the precipitates was much higher for the aged HPT samples than that for the ECAPprocessed and aged counterparts. Due to this effect, the total measured hardness values of the aged HPT specimens were higher than that for the aged ECAP samples even if the dislocation density was lower for the HPT disk at both $120{ }^{\circ} \mathrm{C}$ and $170{ }^{\circ} \mathrm{C}$.

Table 3 reveals that for the HPT sample the hardness decreased by $350 \mathrm{MPa}$ and $660 \mathrm{MPa}$ after aging at $120^{\circ} \mathrm{C}$ and $170{ }^{\circ} \mathrm{C}$, respectively. For both temperatures, about the majority $(\sim 75 \%)$ of this hardness reduction was caused by the annihilation of dislocations and only $25 \%$ can be attributed to the change of grain size and precipitates (transformation from GP zones to $\eta$ phase and coarsening). At the same time, for the ECAP specimen the decrease in the hardness during aging at $120^{\circ} \mathrm{C}$ and $170{ }^{\circ} \mathrm{C}$ was only $240 \mathrm{MPa}$ and $370 \mathrm{MPa}$, respectively, due to the lower driving force for recovery, and the majority (higher than $80 \%$ ) of the hardness decrease was caused by the change of grain size and the precipitate structure. In the latter case, the coarse $\eta$ precipitates formed in the grain boundaries during ECAP were grown during aging at the expense of the GP zones in the vicinity of boundaries which caused a pronounced softening. In the HPT sample, less precipitates were not formed in the grain boundaries, and the softening was caused mainly by the dislocation annihilation during aging due to the high driving force of recovery.

\section{Conclusions}

The evolution of the microstructure and the hardness for a HPT-processed Al-Zn-Mg-Zr alloy was studied during artificial aging at 120 and $170{ }^{\circ} \mathrm{C}$. The following conclusions were drawn from the experimental results:

1. An UFG microstructure with the grain size of $\sim 200 \mathrm{~nm}$ and dislocation density of $\sim 8.0 \times 10^{14} \mathrm{~m}^{-2}$ was formed during HPT. The majority of precipitates were GP zones with the size of $2 \mathrm{~nm}$ which were located in the grain interiors. The average size of the $\mathrm{Mg} / \mathrm{Zn}$-rich and Zr-rich precipitates was 10 and $15 \mathrm{~nm}$, respectively. Peaks of $\eta-\mathrm{MgZn}_{2}$ phase were not observed by XRD due to its very small fraction. It was found that the majority of the hardness was caused by the precipitates.

2. Aging at 120 and $170{ }^{\circ} \mathrm{C}$ resulted in a significant decrease in the dislocation density to $\sim 2.6 \times 10^{14} \mathrm{~m}^{-2}$ and $\sim 0.4 \times 10^{14} \mathrm{~m}^{-2}$, respectively, due to the high driving force of recovery. In addition, a large amount of $\eta-\mathrm{MgZn}_{2}$ particles was formed from the GP zones. The intensity percentage values of $\eta-\mathrm{MgZn}_{2}$ phase were 5 and $8.3 \%$ at 120 and $170{ }^{\circ} \mathrm{C}$, respectively. Moreover, coarsening of both $\mathrm{Mg} / \mathrm{Zn}$-rich and Zr-rich precipitates to $20-25 \mathrm{~nm}$ was also observed. These changes resulted in softening which was mainly caused by the decrease in the dislocation density.

3. The hardness of the HPT-processed sample ( $1970 \mathrm{MPa})$ was much higher than that for 

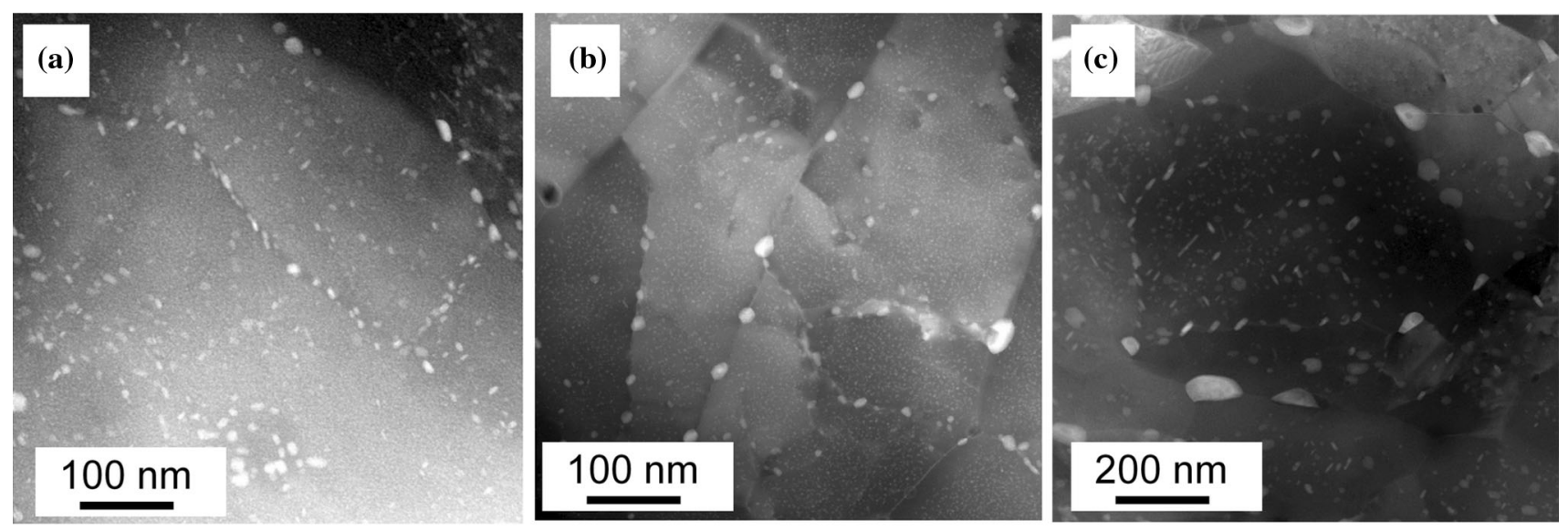

Figure 8 TEM images showing the microstructure for the ECAP-processed sample (a) and the specimens subsequently annealed at 120 (b) and $170{ }^{\circ} \mathrm{C}(\mathbf{c})$.

the same alloy deformed by 4 passes of ECAP ( $1470 \mathrm{MPa})$. This difference can be explained by the effect of the high pressure applied during HPT which hindered the diffusion necessary for the annihilation of dislocations and the formation of $\eta-\mathrm{MgZn}_{2}$ precipitates from the GP zones. Thus, less large $\eta-\mathrm{MgZn}_{2}$ particles were formed in the grain boundaries and more precipitates were found in the grain interiors in the HPT-processed sample which act as obstacles against dislocation motion. This difference between the ECAP and HPT specimens remained valid even after aging at 120 and $170{ }^{\circ} \mathrm{C}$, resulting in a higher hardness for the HPT-processed sample even after annealing.

\section{Acknowledgements}

This research was supported by the Hungarian-Russian bilateral Research program (TÉT) No. 2017-2.3.4TÉT-RU-2017-00005. This work was financed partly by the Ministry of Human Capacities of Hungary within the ELTE University Excellence program (1783-3/2018/FEKUTSRAT). This work was also supported by the project VEKOP-2.3.3-15-2016-00002 of the European Structural and Investment Funds. RZV and MYM acknowledge the support in part from the Ministry of Education of the Russian Federation under grant agreement No. 0838-2020-0006 and part from the Russian Foundation for Basic Research (Project No. 20-03-00614).

\section{Funding}

Open access funding provided by Eötvös Loránd University.

\section{Compliance with ethical standards}

Conflicts of interest The authors declare that there is no conflict of interest.

Open Access This article is licensed under a Creative Commons Attribution 4.0 International License, which permits use, sharing, adaptation, distribution and reproduction in any medium or format, as long as you give appropriate credit to the original author(s) and the source, provide a link to the Creative Commons licence, and indicate if changes were made. The images or other third party material in this article are included in the article's Creative Commons licence, unless indicated otherwise in a credit line to the material. If material is not included in the article's Creative Commons licence and your intended use is not permitted by statutory regulation or exceeds the permitted use, you will need to obtain permission directly from the copyright holder. To view a copy of this licence, visit http://creativecommons.org/licen ses $/$ by $/ 4.0 /$.

\section{References}

[1] Valiev RZ, Zhilyaev AP, Langdon TG (2014) Bulk nanostructured materials - fundamentals and applications. Wiley, Hoboken 
[2] Valiev RZ, Langdon TG (2006) Principles of equal channel angular pressing as a processing tool for grain refinement. Prog Mater Sci 51:881-981

[3] Zhilyaev AP, Langdon TG (2008) Using high-pressure torsion for metal processing: fundamentals and applications. Prog Mater Sci 53:893-979

[4] Gubicza J (2017) Defect structure and properties of nanomaterials. Woodhead Publishing, Duxford

[5] Liddicoat PV, Liao XZ, Zhao Y, Zhu Y, Murashkin MY, Lavernia EJ, Valiev RZ, Ringer SP (2010) Nanostructural hierarchy increases the strength of aluminium alloys. Nat Commun 1(63):1-7

[6] Valiev RZ, Enikeev NA, Murashkin MY, Kazykhanov VU, Sauvage X (2010) On the origin of extremely high strength of ultrafine-grained Al alloys produced by severe plastic deformation. Scr Mater 63:949-952

[7] Zeng ZR, Zhu YM, Bian MZ, Xu SW, Davies J, Birbilis N, Nie JF (2015) Annealing strengthening in a dilute Mg-ZnCa sheet alloy. Scr Mater 107:127-130

[8] Hu J, Shi YN, Sauvage X, Sha G, Lu K (2017) Grain boundary stability governs hardening and softening in extremely fine nanograined metals. Science 355:1292-1296

[9] Zeng W, Shen Y, Zhang N, Huang X, Wang J, Tang G, Shan A (2012) Rapid hardening induced by electric pulse annealing in nanostructured pure aluminum. Scr Mater $66: 147-150$

[10] Valiev RZ, Sergueeva AV, Mukherjee AK (2003) The effect of annealing on tensile deformation behavior of nanostructured SPD titanium. Scr Mater 49:669-674

[11] Gubicza J, Pereira PHR, Kapoor G, Huang Y, Subramanya Sarma V, Langdon TG (2018) Annealing-induced hardening in ultrafine-grained Ni-Mo alloys. Adv Eng Mater 20:1800184

[12] Gubicza J (2020) Annealing-induced hardening in ultrafinegrained and nanocrystalline materials. Adv Eng Mater 22:1900507

[13] Su LH, Lu C, Tieu AK, He LZ, Zhang Y, Wexler D (2011) Vacancy-assisted hardening in nanostructured metals. Mater Lett 65:514-516

[14] Cengeri P, Kerber MB, Schafler E, Zehetbauer JM, Setman D (2019) Strengthening during heat treatment of HPT processed copper and nickel. Mater Sci Eng, A 742:124-131

[15] Tian YZ, Freudenberger J, Pippan R, Zhang ZF (2013) Formation of nanostructure and abnormal annealing behavior of a $\mathrm{Cu}-\mathrm{Ag}-\mathrm{Zr}$ alloy processed by high-pressure torsion. Mater Sci Eng, A 568:184-194

[16] Sun LX, Tao NR, Kuntz M, Yu JQ, Lu K (2014) Annealinginduced hardening in a nanostructured low-carbon steel prepared by using dynamic plastic deformation. J Mater Sci Technol 30:731-735
[17] Darling KA, Kecskes LJ, Atwater M, Semones J, Scattergood RO, Koch CC (2013) Thermal stability of nanocrystalline nickel with yttrium additions. J Mater Res 28:1813-1819

[18] Mondolfo LF (1971) Structure of the aluminium: magnesium: zinc alloys. Int Metall Rev 153:95-124

[19] Polmear IJ (1995) Light alloys-metallurgy of the light metals, 3rd edn. Arnold, London

[20] Lendvai J (1996) Precipitation and strengthening in aluminium alloys. Mater Sci Forum 217-222:43-56

[21] Chinh NQ, Lendvai J, Ping DH, Hono K (2004) The effect of $\mathrm{Cu}$ on mechanical and precipitation properties of $\mathrm{Al}-\mathrm{Zn}$ Mg alloys. J Alloys Comput 378:52-60

[22] Chinh NQ, Gubicza J, Czeppe T, Lendvai J, Xu C, Valiev RZ, Langdon TG (2009) Developing a strategy for the processing of age-hardenable alloys by ECAP at room temperature. Mater Sci Eng, A 516:248-252

[23] Chinh NQ, Győri T, Gubicza J, Lendvai J (2012) Possible self-organized criticality in the Portevin-Le Chatelier effect during decomposition of solid solution alloys. MRS Commun 2:1-4

[24] Valiev RZ, Kazykhanov VU, Mavlyutov AM, Yudakhina AA, Chinh NQ, Murashkin MY (2020) Superplasticity and high strength in AlZnMgZr alloy with ultrfine grains. Adv Eng Mater 22:1900555

[25] Gubicza J, Lábár JL, Lendvai J, Chinh NQ (2019) The influence of artificial aging on the microstructure and hardness of an $\mathrm{Al}-\mathrm{Zn}-\mathrm{Mg}-\mathrm{Zr}$ alloy processed by equal-channel angular pressing. J Mater Sci 54:10918-10928

[26] Kawasaki M, Fifueiredo RB, Langdon TG (2011) An investigation of hardness homogeneity throughout disks processed by high-pressure torsion. Acta Mater 59:308-316

[27] Lee HJ, Han JK, Janakiraman Ahn B, Kawasaki M, Langdon TG (2016) Significance of grain refinement on microstructure and mechanical properties of an $\mathrm{Al}-3 \% \mathrm{Mg}$ alloy processed by high-pressure torsion. J All Comput 686:998-1007

[28] Escobar DH, Rahman ZU, Yilmazer H, Kawasaki M, Boehlert CJ (2019) Microstructural evolution and intermetallic formation in $\mathrm{Zn}-\mathrm{Mg}$ hybrids processed by highpressure torsion. Phil Mag 99:557-584

[29] Escobar DH, Marcus J, Han JK, Unocic RR, Kawasaki M, Boehlert CJ (2020) Effect of post-deformation on the microstructure and micro-mechanical behavior of $\mathrm{Zn}-\mathrm{Mg}$ hybrids processed by high-pressure torsion. Mater Sci Eng, A $771: 138578$

[30] Valiev RZ, Ivanisenko YV, Rauch EF, Baudelet B (1996) Structure and deformation behavior of Armco iron subjected to severe plastic deformation. Acta Mater 44:4705-4712 
[31] Ribárik G, Gubicza J, Ungár T (2004) Correlation between strength and microstructure of ball-milled Al-Mg alloys determined by X-ray diffraction. Mater Sci Eng, A 387-389:343-347

[32] Ungár T, Tichy G, Gubicza J, Hellmig RJ (2005) Correlation between subgrains and coherently scattering domains. Powder Diffr 20:366-375

[33] Priya P, Krane MJM, Johnson DR (2016) Precipitation of $\mathrm{Al}_{3} \mathrm{Zr}$ dispersoids during homogenization of $\mathrm{Al}-\mathrm{Zn}-\mathrm{Cu}-\mathrm{Mg}-$ Zr alloys. Light Met 2016:211-218

[34] Eivani AR, Zhou J, Duszczyk J (2012) A new approach to incorporating the effect of nano-sized dispersoids on recrystallization inhibition into Monte Carlo simulation. Comput Mater Sci 54:370-377

[35] Buranova Y, Kulitskiy V, Peterlechner M, Mogucheva A, Kaibyshev R, Divinski SV, Wilde G (2017) Al3(Sc, Zr)based precipitates in Al-Mg alloy: effect of severe deformation. Acta Mater 124:210-224

[36] Orlova TS, Mavlyutov AM, Latynina TA, Ubyivovk EV, Murashkin MY, Schneider R, Gerthsen D, Valiev RZ (2018) Influence of severe plastic deformation on microstructure, strength and electrical conductivity of aged $\mathrm{Al}-0.4 \mathrm{Zr}(\mathrm{Wt} \%)$ alloy. Rev Adv Mater Sci 55:92-101

[37] Zhang Y, Jin S, Trimby P, Liao X, Murashkin MY, Valiev RZ, Sha G (2019) Strengthening mechanisms in an ultrafinegrained $\mathrm{Al}-\mathrm{Zn}-\mathrm{Mg}-\mathrm{Cu}$ alloy processed by high pressure torsion at different temperatures. Mater Sci Eng, A 752:223-232

[38] Tabor D (1951) Hardness of metals. Clarendon Press, Oxford

[39] Gubicza J, Chinh NQ, Lábár JL, Hegedűs Z, Xu C, Langdon TG (2008) Microstructure and yield strength of severely deformed silver. Scr Mater 58:775-778

[40] Furukawa M, Horita Z, Nemoto M, Valiev RZ, Langdon TG (1996) Microhardness measurements and the Hall-Petch relationship in an Al-Mg alloy with submicrometer grain size. Acta Mater 44:4619-4629

[41] Furukawa M, Iwahashi Y, Horita Z, Nemoto M, Tsenev NK, Valiev RZ, Langdon TG (1997) Structural evolution and the
Hall-Petch relationship in an Al-Mg-Li-Zr alloy with ultrafine grain size. Acta Mater 45:4751-4757

[42] Farhat ZN, Ding Y, Northwood DO, Alpas AT (1996) Effect of grain size on friction and wear of nanocrystalline aluminum. Mater Sci Eng, A 206:302-313

[43] Zehetbauer MJ, Stüwe HP, Vorhauer A, Schafler E, Kohout J (2003) The role of hydrostatic pressure in severe plastic deformation. Adv Eng Mater 5:330-337

[44] Schafler E (2010) Effects of releasing the hydrostatic pressure on the nanostructure after severe plastic deformation of Cu. Scr Mater 62:423-426

[45] Gubicza J, Dobatkin SV, Khosravi E, Kuznetsov AA, Labar JL (2011) Microstructural stability of $\mathrm{Cu}$ processed by different routes of severe plastic deformation. Mater Sci Eng, A 528:1828-1832

[46] Schafler E, Steiner G, Korznikova E, Kerber M, Zehetbauer MJ (2005) Lattice defect investigation of ECAP-Cu by means of X-ray line profi le analysis, calorimetry and electrical resistometry. Mater Sci Eng, A 410:169-173

[47] Setman D, Schafler E, Korznikova E, Zehetbauer MJ (2008) The presence and nature of vacancy type defects in nanometals detained by severe plastic deformation. Mater Sci Eng, A 493:116-122

[48] Kuzel R, Janecek M, Matej Z, Cizek J, Dopita M, Srba O (2010) Microstructure of equal-channel angular pressed $\mathrm{Cu}$ and $\mathrm{Cu}-\mathrm{Zr}$ samples studied by different methods. Metall Mater Trans A 41:1174-1190

[49] Cizek J, Janecek M, Srba O, Kuzel R, Barnovska Z, Prochazka I, Dobatkin S (2011) Evolution of defects in copper deformed by high-pressure torsion. Acta Mater 59:2322-2329

[50] Su LH, Lu C, Deng GY, Tieu K, Zhang LC, Guagliardo P, Samarin SN, Williams JF (2014) Vacancy-type defects study on ultra-fine grained aluminium processed by severe plastic deformation. Sci Adv Mater 6:1338-1345

Publisher's Note Springer Nature remains neutral with regard to jurisdictional claims in published maps and institutional affiliations. 